\section{THE VENEZUELA AND BRITISH GUIANA BOUNDARY.}

THE sudden accession of an acute phase in the question of the boundary-line between British Guiana and Venezuela, has attracted the attention of the whole world to a controversy which has been proceeding intermittently for nearly a century. With its political aspect the pages of NATURE have no concern ; but from another point of view it affords an opportunity for enforcing some of those scientific principles of geography, the ignorance or neglect of which has done much to embarrass the relations between neighbouring countries.

The fundamental error is to suppose that any piece of land on the face of the globe is so worthless that its ownership once claimed may be left undefined. So long as forest or plantation products alone, or mining alone, or any other partial potentiality of land is considered by itself, it is perfectly natural for colonists and governments to postpone expensive surveys of tracts that promise no immediate advantages, or to delay troublesome negotiations. In the end more trouble and more expense have to be faced, often in unexpected quarters.

Political geography is no longer a matter to be treated tentatively by politicians, any more than industrial chemistry is now a matter for the uninstructed experiments of tradesmen. It is the highest outcome of geographical theory, a theory which deals without a break with all terrestrial distributions, from the primary elements of geomorphology and climatology, to the adjustment of life to environment in the progressively more complex cases of plant, animal, and man. So little attention has been paid in this country to geography as a science with a definite purpose, and so few explorers have been equipped with even an elementary acquaintance with the principles of geography, that we gladly seize this opportunity to urge the importance of geographical theory as a guide to the prevision and prevention of frontier-disputes.

Two stages are necessary in arranging a frontierdrawing it on a map, and demarcating it on the ground. For the former purpose it is easiest to take a mathematical line, a meridian or parallel ; for the latter some distinct physical feature, and of these there are only two which can be looked on as satisfactory-a watershed or a Thalweg. In practice the Thalweg, which is the line along which converging slopes meet, as the watershed is the line along which diverging slopes meet, means the central line of a river. The sea counts as neutral territory in all international affairs, and the coast-line requires no definition. The position of a parallel may be determined astronomically with great exactness, and, when marked on the ground by posts within sight of each other, is perfectly explicit; but it involves highly-skilled work and the agreement of two parties of expert surveyors. The case of a meridian may also be settled, but can rarely be free from the risk of rectifications being demanded, as more exact methods of determining longitude become available. Noteworthy exchanges of territory may thus be necessitated, perhaps involving hardships to individuals. A great mountain seems a peculiarly fitting corner-stone for the meeting of national frontiers, and is so used in the case of Mount Ararat ; but Mount St. Elias has had to change its nationality by the rectification of the meridian of $14 \mathrm{I}^{\circ} \mathrm{W}$. Such a boundary-line as that between the southern part of Alaska and British Columbia, a line parallel to the coast, and ten leagues distant from it, represents perhaps the least scientific frontier on the face of the earth. It might be possible, when large scale maps are made of the fjord-riven coast, to draw this line on them; but only mutual goodwill and concessions could ever have allowed it to be even approximately marked on the ground.

In the particular instance before us, a map published by the Venezuelan Government in 1890 , which it is impossible to reproduce on a small scale without the use of colour, shows the ten hypothetical western boundaries of British Guiana which have been put forward by one side or the other in the course of negotiations. Most of these lines are an outrage on geography, and it is difficult to believe that some of them were seriously put forward by the statesmen whose names they bear. We have been unable to find any British map showing these proposed boundaries, and it does not appear that our Foreign Office has published one. The boundaries in many cases cut natural features and mathematical lines at all angles and in irregular curves which it would be impossible either to describe verbally or to lay out accurately on the ground without a survey as minute as for a railway. These we do not require to dwell on, except in the way of pointing the moral that the results of geography should be officially recognised by Government departments more fully than has hitherto been the case. The Intelligence Division of the War Office is, in a sense, the Government Geographical Department, but it is concerned mainly with the practical work for the Army, and might well be supplemented by a more purely geographical office. It is true that the Royal Geographical Society is always ready to render help when called upon, and does not infrequently answer questions as to matters of fact. What is wanted, however, is rather an official geographer who may be consulted by the Government on matters of geographical theory as well as of fact, and who might be charged with the duty of preparing and keeping up to date an official geography of the British Empire.

The geographical conditions of the present boundary difficulty can be stated easily, so far as the main features are concerned; but the details are many and complicated. A boundary dispute in itself is a quite normal condition in South America. The boundaries of every republic in that continent are disputed; in several cases three neighbouring countries claim the same territory. It is impossible to draw a political map of South America, even on the smallest scale, that would be generally acceptable. In the case of Guiana, it is well to look at the physical condition of the land before tracing the contested boundaries. From the mouth of the Orinoko to the mouth of the Amazon the coast of South America runs nearly south-east, and the distance is Iooo miles. A line drawn from river to river, about 500 miles inland from the coast and parallel with the coastline, contains the whole region known as Guiana. It consists of a gently rising plateau of Archæan rocks edged by very low plains of quaternary formation, bordering the Orinoko on the north, the Atlantic on the north-east, the Amazon on the south, and forming the llanos of the Ria Negro and Upper Orinoko on the south-west. The plateau bears a number of low mountain ranges, which have been made familiar by recent explorations; the Tumak-humak, Akarai, Pacaraima (including Roraima), Parime and Imataka, amongst others. The trade winds bring a heavy and regular rainfall to the whole eastern slope, causing it to be clothed with perhaps the richest and densest tropical forests of the world. On the top of the plateau, and on the western slopes, there is a reduced rainfall, and in accordance with this savannahs take the place of woods. Many large rivers carry off the surplus rainfall ; of these we may name, on the north-eastern slope, from south to north, the Araguary, Oyapok, Maroni, Korentin, Essequibo (including the Mazaruni and Kuyuni), and, turning north-westward towards the sea, the Barama (or Guiana), Barima, and Amakuru. Every one of these rivers flows through dense primeval forests for the greater part of its course, and discharges on a muddy coast-line, which is rapidly growing seawards, thanks to the aid of mangroves.

On the south-western slopes the rivers are much longer,

NO. I 366 , vOL. 53] 
and flow to the Amazon and the Orinoko, the two great river-systems being connected, as is well known, by the natural canal of the Casiquiare. The more westerly rivers flow, for the most part, through open savannah country; so that the water-shed of the plateau is much more accessible from the Orinoko on the west and north than it is from the Atlantic on the north and east. From Mount Roraima south-eastward Thalwegs of the upper tributaries of the Rio Branca form a political boundary to near the source of the Essequibo, after which the watershed is a political boundary, the whole southern slope (except a small portion of the Rio Branco basin included in British Guiana) constituting Brazilian Guiana. From Roraima westward the whole area draining to the Orinoko River incontestably belongs to Venezuela. The present frontier disputes concern the forest-covered Atlantic drainage area, which is shared by the only three colonies remaining in South America-British Guiana on the west, Dutch Guiana in the centre, and French Guiana to the east. Here most of the boundaries are Thalwegs, i.e. the central line of rivers. There is no question as to Dutch Guiana, which is demarcated by treaty from British Guiana by the Korentin, and from French Guiana by the Maroni. But here certainty ends. The French and Dutch differ as to which of the upper tributaries of the Maroni should be taken as the boundary between Dutch and French territory. The Brazilian Government recognises the Oyapok as the French boundary toward Brazil ; the French claim the Araguary, the space between the two rivers which flow nearly at right angles to each other being a triangle with 250 miles of coast as a base. The uncertainty of boundaries at the east of Guiana is simpler to understand, and easier to explain than that at the west. The claim of Venezuela is that British Guiana is bounded by the Thalweg of the Essequibo, and it is so represented on Venezuelan maps. The extreme British claim, on the other hand, is that the whole drainage area of the Essequibo belongs to the colony, i.e. that the boundary is the main watershed of the plateau as far as the Imataka range on the north, which runs parallel to and very near the Orinoko. In addition, there is a claim for the basins of the small rivers which occupy the triangular area between the drainage areas of the Orinoko and the Essequibo. If the western boundary of British Guiana were to be of the same type as those of the other colonies, it would require to be the Thalweg of a river flowing into the Atlantic, i.e. either the Essequibo, the Mazaruni, the Kuyuni (these three unite to enter the sea at a common mouth), or the Barama (Guiana), Barima, or Amakura.

It is now too late to suggest the solution of the bound ary problem by geographical principles. Were it not so, a very interesting argument could be held as to how far the physical unity of a drainage basin is impaired by the obstacles to movement along the Thalweg due to cataracts interrupting navigation on the rivers, and forests obstructing progress on land. It is, in fact, very much easier to reach the upper basin of the Kuyuni branch of the Essequibo over the savannahs from the Orinoko than through the forests from the Atlantic coast.

All modern maps of Guiana - except the Venezuelanfollow what is known as Schomburgk's boundary, either in its original or in a modified form.

In 1840 the Schomburgk line first appeared on a sketch map, the topography of which was very inexact. From the Amakuru River in the north it ran along the watershed southwards, thus leaving the whole basin of the Barima in British Guiana. It so happened that the line ran nearly on the meridian of $60^{\circ} \mathrm{W}$. as far as the Kuyuni River; and when the Barima was found to rise far to the west of that meridian, the line was often still drawn along it, instead of following the watershed as was intended. In 1886 the British Government modified the line by carrying it along the Kuyuni River to its source, and then for a short distance along the watershed, to Roraima.

The whole area within the Schomburgk line has been taken into effective possession by the Government of British Guiana so far as a tropical forest of such magnitude can be occupied. The Barima River was recently explored to its source by Mr. G. G. Dixon, and the account of his journey in the Geographical Journal, for April I 895, gives some idea of the difficulty of forcing a way through the woods. Much of the land is auriferous, and the real point of the present frontier difficulty lies in the value of Yuruari mines in the upper basin of the Kuyuni, at present occupied politically by Venezuela, and commercially by the nondescript cosmopolitan population always attracted to gold-fields.

It is this fact that makes it hopeless to expect the dispute to be settled by the geographical principles which forty years ago could have easily prevented it. The only alternatives are to base the rival claims on actual effective possession, or on the original rights which were recognised between the Dutch settlers in Guiana and the Spanish colonists of the Orinoko at a time when the geography of the district was practically unknown. The romantic story of British enterprise in Guiana is admirably told in Lucas' "Historical Geography of the British Colonies," vol. ii., a work of admirable clearness and brevity.

D'Anville's atlas of 1772 shows practically the whole of the disputed area as Dutch Guiana, but contemporary and later maps are very conflicting, and all of them being unofficial are of small value as evidence. The chart of Captain Edward Thompson, who took part in the first capture of the "Wild Coast" from the Dutch in I78I, marks the Barima as "the western boundary of the Dutch according to their claim," but does not suggest any boundary in the interior. The rights and wrongs of historic evidence will doubtless be fully investigated by those responsible for a decision, and the present dispute will probably be settled, as similar difficulties have been settled before, by some judicious compromise which will give both parties the inestimable benefit of a fixed and definite frontier. But similar disputes will continue to arise in other places, and their solution will be protracted and rendered difficult as long as unsurveyed territory is claimed by rival powers, spurred on by rival concessionaires and interested company promoters.

The recent International Geographical Congress decided that the time had come when all governments should be urged to make a map of their possessions on the uniform scale of I : I, $, 00,000$, or about sixteen miles to an inch. If the governments of all countries were jointly to take this matter up, survey all unsurveyed lands which they claim, and submit the uncertain boundaries, which are not yet complicated by goldmines, to an International Commission of Geographers, to be decided on the basis of the new map on purely geographical principles, the expense would be many times saved by the security which defined frontiers give, and a magnificent contribution to science would be effected. HUGH ROBERT MiLl.

\section{DR. JOHN RUSSELL HIND, F.R.S.}

$\mathrm{T}$ is with deep regret that we announce the death of Dr. J. R. Hind, whose name and whose work were possibly more familiar to astronomical students of the last generation than they are to those of to-day. By this we do not mean to imply that Dr. Hind had outlived his reputation, but that circumstances forced him to the front early in life and in connection with subjects that have long since ceased to attract or to interest. His claim to scientific reputation and remembrance will

No. т 366 , vOL. 53 ? 